\title{
Improved Real-Time PCR Diagnosis of Citrus Stubborn Disease by Targeting Prophage Genes of Spiroplasma citri
}

Xuefeng Wang, National Citrus Engineering Research Center, Citrus Research Institute, Southwest University, Chongqing 400712, P. R. China; Harsha Doddapaneni, Department of Biology, University of Iowa, Iowa City 52242; and Jianchi Chen and Raymond K. Yokomi, United States Department of Agriculture-Agricultural Research Service (USDA-ARS), San Joaquin Valley Agricultural Sciences Center, Parlier, CA 93648-9757

\begin{abstract}
Wang, X., Doddapaneni, H., Chen, J., and Yokomi, R. K. 2015. Improved real-time PCR diagnosis of citrus stubborn disease by targeting prophage genes of Spiroplasma citri. Plant Dis. 99:149-154.

Spiroplasma citri is a phloem-limited bacterium causing citrus stubborn disease (CSD). Isolation and culturing of $S$. citri is technically demanding and time consuming. S. citri is typically low in titer and unevenly distributed in citrus, making reliable detection challenging. The current preferred detection method is polymerase chain reaction (PCR) assays with primers developed from sequences of $S$. citri housekeeping genes. Recent genome sequencing of $S$. citri revealed that the bacterium harbors multiple copies of prophage genes. Therefore, targeting multicopy prophage genes was hypothesized to improve sensitivity of PCR detection. Two primer sets, Php-orf1 and Php-orf3, were developed from conserved prophage sequences in the $S$. citri genome. These primer sets were used to evaluate detection sensitivity in SYBR Green-based quantitative PCR (qPCR) assays with $18 \mathrm{~S}$. citri in cul-

Php-orf1 increased detection sensitivity by 4.91 and 3.65 cycle threshold $(\mathrm{Cq})$ units compared with housekeeping gene primers for spiralin and P58 putative adhesin gene, respectively. Detection was slightly less sensitive for the Php-orf3 primer set at 3.02 and $1.76 \mathrm{Cq}$ units, respectively, over the same housekeeping gene primers. The prophage primer sets were validated for qPCR detection with field samples from three citrus orchards in California's San Joaquin Valley collected from 2007 to 2013. The data showed that $S$. citri prophage sequences improved sensitivity for qPCR detection of $S$. citri-infected trees at least 10 -fold and reduced the number of false-negative results. No false-positive samples were detected with any of the primer sets. The enhanced sensitivity resulted from the higher copy number of prophage genes in the $S$. citri genome and, thus, improved CSD diagnosis from field samples.
\end{abstract} tures isolated from different hosts and locations. Prophage primer set
Spiroplasma citri is a fastidious wall-less bacterium in the class Mollicutes. The bacterium infects citrus, causing citrus stubborn disease (CSD) in California, Arizona, North Africa, and the Mediterranean Basin (3). S. citri also has a wide host of nonrutaceous plant species $(9,19)$. Recently, $S$. citri was reported to have been isolated from infected periwinkle in Malaysia (20). S. citri in citrus is spread by using infected budwood to propagate new trees or by transmission by several species of leafhoppers in a propagative manner $(15,21)$. S. citri infection stunts citrus growth and decreases fruit production but does not kill trees. Typical symptoms include stunted growth of canopy, small leaves and bunchy upright growth, chlorosis with zinc-like deficiency, premature fruit drop, low yield, and smaller or misshapen fruit (5). In California, CSD is a problem in the San Joaquin Valley and desert regions where hot, dry weather favors development of $S$. citri in various plant hosts and the beet leafhopper, Circulifer tenellus, principle vector of $S$. citri in this region (21).

Early detection of $S$. citri infection is important for CSD management. However, CSD is difficult to diagnose, especially in early

Corresponding author: R. K. Yokomi, E-mail: ray.yokomi@ars.usda.gov

Current address of H. Doddapanneni: Human Genome Sequencing Center, Baylor College of Medicine, Houston, TX 77030.

Mention of trade names or commercial products in this publication is solely for the purpose of providing specific information and does not imply recommendation or endorsement by the United States Department of Agriculture (USDA). USDA is an equal opportunity provider and employer.

Accepted for publication 26 July 2014.

http://dx.doi.org/10.1094/PDIS-06-14-0572-RE

This article is in the public domain and not copyrightable. It may be freely reprinted with customary crediting of the source. The American Phytopathological Society, 2015. stages of disease development when symptoms are subtle or similar to other diseases or mineral deficiencies. Because $S$. citri isolation is technically demanding and time consuming, current detection is typically polymerase chain reaction (PCR)-based, using primers developed from sequences of housekeeping genes such as 16S ribosomal RNA (rRNA), spiralin, and the adhesin gene $(12,29,30)$. Because of erratic distribution and low titer $(9,29), S$. citri DNA may not be reliably detectable by PCR using primers to sequences of low-copy genes in citrus.

To improve sensitivity of PCR detection, phage or prophage sequences of $S$. citri were used with good promise for detection in another study (12). The $S$. citri has the largest genome (1.6 to 1.9 $\mathrm{Mbp}$ ) of all Mollicutes tested (24,27). This genome contains ubiquitous phage-related sequences such as plectrovirus $\mathrm{SpV} 1$, which was isolated and sequenced from $S$. citri R8A2 B (22). S. citri contained multiple dispersed copies of SpV1-related sequences which apparently play an important role in $S$. citri chromosomal rearrangement $(16,27)$. More recently, a partial chromosome sequence of $S$. citri strain GII3-3X was reported and showed that phage-related and prophage sequences accounted for $20.5 \%$ of the sequenced genome (7).

Conserved multicopy DNAs provides higher template concentration for PCR detection. Therefore, it was hypothesized that PCR targeting phage or prophage genes may yield more sensitive detection than that from housekeeping genes. In this study, two primer sets, Php-orf1 and Php-orf3, were developed from prophage sequences in the $S$. citri genome. SYBR Green-based real time quantitative PCR (qPCR) was performed to evaluate detection sensitivity with $S$. citri cultures and validated with field samples from citrus orchards.

\section{Materials and Methods}

Bacterial strains. Eighteen $S$. citri strains were used in this study (Table 1). The source and isolation date were reported previously (17). Eleven of the strains were provided by Jacqueline 
Fletcher, Oklahoma State University, Stillwater, and are identified in Table 1 by a footnote. Cultivation was performed using standard procedures in LD8 medium (29) and strains were triply cloned and stored at $-80^{\circ} \mathrm{C}$ (29). Primer specificity was evaluated using DNA extracted from the cultures as well as from infected plants harboring 'Candidatus Liberibacter asiaticus', ' $C a$. L. solanacearum', Xylella fastidiosa, and Xanthomonas citri subsp. citri (Table 1).

Library preparation, Illumina sequencing, and assembly. Genomic DNA (50 ng) was fragmented with a modified transposition reaction called "tagmentation" with the Nextera DNA Sample Prep Kit (Epicentre Biotechnologies, Madison, WI). Eight different 6-bp barcoded adapters provided in the kit were used to prepare libraries compatible to Illumina sequencing. The resultant libraries, one for each strain of $S$. citri, were pooled together and sequenced on a single lane of the Illumina Genome Analyzer IIx at The University of Iowa. Two rounds of sequencing (72-bp single read and $2 \times 72$-bp paired-end reads) were carried out followed by demultiplexing of data for each library into separate fastq files. A range of $633 \mathrm{Mb}$ and $1.019 \mathrm{~Gb}$ of sequence data was generated for each strain. Assuming that the genome size of $S$. citri is $1.8 \mathrm{Mb}(28)$, this accounts for $351 \times$ to $566 \times$ genome coverage. Each strain was assembled by combining the single and paired-end data using SOAPdenovo-V1.05 software (13). A range of K-mers was tried to generate optimal assemblies for each strain (Table 2).
Copy number analysis of the five genes. DNA libraries from the eight $S$. citri strains subjected to Illumina sequencing resulted in greater than $90 \%$ genome sequence for each of the eight strains (Table 2). These were compared with the complete genome of SpV1-R8A2 B (accession number X51344) and partial chromosome sequences of $S$. citri strain GII3-3X (accession number AM285301-AM285339) obtained from the GenBank database in the National Center for Biotechnology Information (NCBI; http://www.ncbi.nlm.nih.gov/). Due to the high abundance and multicopy sequences of SpV1-ORF1 and SpV1-ORF3, two phagerelated genes in strain GII3-3X, these two genes were selected for further analysis (Table 3). The blast+ software package for standalone BLAST was downloaded from NCBI (6). 16S rRNA, spiralin gene, P58 gene, and two prophage genes were used as queries for local BLASTn search $\left(E<\mathrm{e}^{-5}\right)$ against contigs of eight S. citri strains and strain GII3-3X, respectively (Table 2).

Primer design. Two primer sets for qPCR were designed with Primer 3 software (23). Primers from spiralin and the putative adhesin gene (P58) gene were designed based on previous reports $(29,30)$. All primer sets used in the study are listed in Table 3.

qPCR. qPCR assays based on SYBR Green included the newly developed Php-orf1 and Php-orf3 primer sets for sensitive detection and spiralin and P58 primer sets for comparison purposes. The reaction cocktail consisted of $25 \mu \mathrm{l}$ of reaction mixture containing $12.5 \mu \mathrm{l}$ of iQ SYBR Green Supermix (Bio-Rad), $0.2 \mu \mathrm{M}$ each pri-

Table 1. Diagnostic sensitivity and specificity of real-time polymerase chain reaction base on four primers for the detection of Spiroplasma citri strains

\begin{tabular}{|c|c|c|c|c|c|c|}
\hline \multirow[b]{2}{*}{ Strain } & \multirow[b]{2}{*}{ Host } & \multirow[b]{2}{*}{ Origin } & \multicolumn{4}{|c|}{ Cycle threshold values ${ }^{a}$} \\
\hline & & & Spiralin & P58 & Php-orf1 & Php-orf3 \\
\hline Spiroplasma citri $\mathrm{Ca} 1$ & Navel & Tulare County, CA & 9.77 & 8.84 & 4.85 & 6.86 \\
\hline S. citri $\mathrm{Ca} 16$ & Navel & Tulare County, CA & 12.85 & 11.34 & 8.32 & 9.47 \\
\hline S. citri $\mathrm{Ca} 263$ & Lambs quarter & Fresno County, CA & 9.45 & 9.08 & 4.47 & 7.63 \\
\hline S. citri $\mathrm{Ca} 264$ & Daikon & Fresno County, CA & 8.16 & 6.87 & 3.46 & 5.28 \\
\hline S. citri CB1 & BLH & Fresno County, CA & 9.52 & 9.45 & 4.63 & 6.80 \\
\hline S. citri C5 & Carrot & Kern County, CA & 12.23 & 10.95 & 7.62 & 9.33 \\
\hline S. citri $\mathrm{C} 17$ & Carrot & Kern County, CA & 10.29 & 9.43 & 6.03 & 7.14 \\
\hline S. citri $\mathrm{O} 202^{\mathrm{b}}$ & Peach & California & 10.02 & 8.41 & 4.96 & 6.41 \\
\hline S. citri $\mathrm{O} 15^{\mathrm{b}}$ & Broccoli & California & 12.15 & 10.41 & 7.28 & 9.26 \\
\hline S. citri $\mathrm{BR} 3^{\mathrm{b}}$ & Horseradish & Illinois & 9.31 & 8.64 & 4.66 & 6.67 \\
\hline S. citri $\mathrm{BR}^{\mathrm{b}}$ & Horseradish & Illinois & 8.68 & 7.38 & 3.22 & 5.53 \\
\hline S. citri $\mathrm{BR} 11^{\mathrm{b}}$ & Horseradish & Illinois & 10.59 & 8.63 & 5.38 & 7.98 \\
\hline S. citri MDHR2 $2^{\mathrm{b}}$ & Horseradish & Maryland & 11.41 & 8.79 & 5.41 & 7.31 \\
\hline S. citri MDHR4 ${ }^{\mathrm{b}}$ & Horseradish & Maryland & 8.99 & 6.66 & 3.70 & 5.07 \\
\hline S. citri $\mathrm{R} 8 \mathrm{~A} 2^{\mathrm{b}}$ & Sweet orange & Morocco & 10.28 & 9.40 & 4.97 & 6.60 \\
\hline S. citri Beni ${ }^{\mathrm{b}}$ & Sweet orange & Morocco & 12.02 & 11.93 & 8.37 & 10.05 \\
\hline S. citri $\operatorname{Iran}^{\mathrm{b}}$ & Sweet orange & Iran & 11.71 & 9.28 & 6.74 & 7.98 \\
\hline S. citri ASP $1^{\mathrm{b}}$ & Sweet orange & Israel & 8.00 & 7.23 & 3.01 & 5.71 \\
\hline 'Candidatus Liberibacter asiaticus' GD-A4 & Sweet orange & Guangdong, China & NA & NA & NA & NA \\
\hline 'Ca. L. asiaticus' CAHLB2012Las1 & Pummelo/Lemon & Los Angeles County, CA & NA & NA & NA & NA \\
\hline Xanthomonas citri subsp. citri XC62 & Citrus sp. & Japan & NA & NA & NA & NA \\
\hline Xylella fastidiosa M12 & Almond & California & NA & NA & NA & NA \\
\hline$X$. fastidiosa Dixon & Almond & California & NA & NA & NA & NA \\
\hline 'Ca. L. solanacearum' & Potato & Riverside, CA & NA & NA & NA & NA \\
\hline
\end{tabular}

a NA = not applicable.

${ }^{\mathrm{b}}$ Culture provided by Jaqueline Fletcher, Oklahoma State University, Stillwater. Original source material described by Mello et al. (17).

Table 2. Copy number of five genes in Illumina data from eight strains and submission sequences of GII3-3X

\begin{tabular}{|c|c|c|c|c|c|c|c|c|}
\hline \multirow[b]{2}{*}{ Strain } & \multirow[b]{2}{*}{ Total length (bp) } & \multirow[b]{2}{*}{ Contigs (>100 bp) } & \multirow[b]{2}{*}{ Contigs (N50) } & \multicolumn{5}{|c|}{ Copy number } \\
\hline & & & & 16S rRNA & Spiralin & P58 & SpV1-ORF1 & SpV1-ORF3 \\
\hline Ca1 & $1,860,679$ & 3,375 & 59 & 1 & 1 & 5 & 54 & 18 \\
\hline $\mathrm{Ca} 263$ & $2,117,582$ & 4,358 & 77 & 1 & 1 & 1 & 154 & 26 \\
\hline $\mathrm{Ca} 264$ & $2,381,867$ & 6,324 & 223 & 1 & 1 & 3 & 115 & 8 \\
\hline CB1 & $1,692,836$ & 2,686 & 60 & 1 & 1 & 3 & 56 & 19 \\
\hline C5 & $1,706,281$ & 2,702 & 55 & 1 & 1 & 5 & 55 & 29 \\
\hline BR11 & $1,742,002$ & 2,904 & 53 & 1 & 1 & 5 & 46 & 22 \\
\hline R8A2 & $1,994,329$ & 4,097 & 134 & 1 & 1 & 5 & 93 & 35 \\
\hline Iran & $2,450,939$ & 5,836 & 270 & 1 & 3 & 1 & 140 & 56 \\
\hline GII3-3X & $1,525,756^{a}$ & 39 & $\ldots$ & 1 & 1 & 1 & 13 & 11 \\
\hline
\end{tabular}

a This is the nucleotide acid number deposited in the National Center for Biotechnology Information database. The estimated chromosome length of GII3-3X is $1,820 \mathrm{kbp}(7)$. 
mer, and $1 \mu \mathrm{l}$ of DNA extract from field plants or $S$. citri cell culture DNA. Amplification, detection, and data analysis were performed with an ABI PRISM 7000 Sequence Detection System (Applied Biosystems, Foster City, CA). The thermal profile consisted of one step at $95^{\circ} \mathrm{C}$ for $5 \mathrm{~min}$. followed by 35 cycles of $95^{\circ} \mathrm{C}$ for $20 \mathrm{~s}, 58^{\circ} \mathrm{C}$ for $30 \mathrm{~s}$, and $72^{\circ} \mathrm{C}$ for $30 \mathrm{~s}$. Alternatively, a CFX96 Real-Time System with a C1000 thermal cycler (Bio-Rad Laboratories, Hercules, CA) was used where the thermal profile consisted of one step at $95^{\circ} \mathrm{C}$ for $3 \mathrm{~min}$ followed by 35 cycles of $95^{\circ} \mathrm{C}$ for 10 $\mathrm{s}$ and $59^{\circ} \mathrm{C}$ for $30 \mathrm{~s}$.

qPCR sensitivity. To determine the analytic sensitivity and amplification efficiency of the qPCR assays, standard curves relating the amount of fluorescence to genomic DNA concentrations of $S$. citri per reaction were constructed using a series of 10 -fold dilutions of LB10 cell culture DNA. S. citri was cultured in $25 \mathrm{ml}$ of LD8 broth to a log stage and adjusted 20,000 cells/ $\mu$ with a hemacytometer (C-Chip; Incyto, Covington, GA) with a dark-field compound microscope. DNA was extracted from an aliquot of 20,000 $S$. citri cells/ $\mu$ by cetyltrimethylammonium bromide (CTAB) (8) and used at $1 \mu \mathrm{l}$ per reaction for each 10 -fold dilution up to $10^{-4}$. The DNA concentration was estimated to range from $64 \mathrm{pg}$ to $0.064 \mathrm{fg}$ per reaction. Three replicates of each dilution were tested simultaneously in the same run and four independent assays were performed. A linear relationship was produced by plotting the log DNA concentration against cycle threshold $(\mathrm{Cq})$ value. qPCR amplification efficiency was estimated from the slopes of the standard curves using the equation $\mathrm{E}=10^{-1 / \text { slope }}-1$.

Field sample collection. To test and validate efficacy and sensitivity of the new primers, citrus fruit or leaves from three different orchards in the San Joaquin Valley were collected from the same plot trees from 2007 to 2013: (i) 22 S. citri-positive trees of 'Powell Navel' on 'Carrizo' citrange rootstock near Huron, Fresno County, CA; (ii) 51 S. citri-positive trees of 'Spring Navel' on Carrizo near Ducor, Tulare County, CA (Table 4); and (iii) 568 S. citripositive and -negative trees of 'Cara Cara' on Carrizo near Mettler, Kern County, CA (Table 5). Leaves or fruit were harvested from all quadrant of each tree, labeled, and stored in ziplock bags at $4^{\circ} \mathrm{C}$ until processed. Purified DNA extracts were stored at $-80^{\circ} \mathrm{C}$ until needed for the PCR testing. Primer set validation using Huron and Ducor trees included samples which previously were determined to be $S$. citri positive (30). The Mettler plot represented a second validation test in which the status of $S$. citri infection was unknown; thus, each tree in the plot was sampled and tested twice over a 2-year period.

DNA extraction. Fresh fruit columella tissue $(200 \mathrm{mg})$ from three fruits or 10 leaf midribs per tree were excised and homogenized in a Homex 6 homogenizer (BioReba AG, Reinach, Switzerland). DNA was extracted by a CTAB method (8). A highthroughput extraction protocol was used for the 2013 plots from Mettler. A nucleic acid isolation kit (NucleoMag 96; MachereyNagel Inc., Bethlehem, PA) using magnetic beads was used in a BioSprint 96 (Qiagen Inc., Valencia, CA) instrument (25). DNA concentrations and purity were estimated by a NanoDrop ND-100 spectrophotometer (Wilmington, DE). Nucleic acid quality was determined using a plant cytochrome-oxidase-based primer-probe set as positive internal control to assess the quality of DNA extracts (14). Resultant $\mathrm{Cq}$ values were always between 17 and 19 for both CTAB and high-throughput extractions.
Statistical analysis. Analysis of variance (ANOVA) was performed on the means of $\mathrm{Cq}$ values using a single-factor ANOVA with a confidence level of $P=0.05$.

\section{Results}

Illumina sequencing. Assembly of data resulted in 2,686 to 6,324 contigs of $100 \mathrm{bp}$ or greater in length that were considered for further analyses. This accounts four $1.45 \mathrm{Mb}$ to $1.85 \mathrm{Mb}$ of assembled sequence in these strains (Table 2). The N50 contig size in these strains varied between 3.4 and $13.6 \mathrm{~kb}$ and the number of contigs in this N50 assembly varied between 53 and 270 contigs.

Estimation of gene copy numbers. Copy numbers of the five target genes in the eight $S$. citri genomes are shown in Table 2 . Only one copy of $16 \mathrm{~S}$ rRNA gene was identified in each of the eight genomes. Moreover, the spiralin gene was found as a single copy in seven of the genomes but was found with three copies in the Iranian strain, whereas the copy numbers of P58 gene ranged from one to five. In contrast, copy numbers of the two prophage genes were significantly higher, ranging from 54 to 154 for SpV1ORF1 and 8 to 56 for SpV1-ORF3. The strain GII3-3X genome data was assembled into 39 contigs, whereas it was 53 to 270 for the other eight strains (Table 2).

Specificity and sensitivity analyses of four primer sets. In silico analysis indicated that the Php-orf3 primer set was specific for S. citri, whereas Php-orf1 matched with S. citri and S. kunkelii. qPCR specificity tests with primer sets Php-orf1, Php-orf3, spiralin, and P58 were evaluated with DNA extracts from cultures of 18 strains of $S$. citri originally obtained from a variety of hosts, including citrus, carrot, peach, broccoli, horseradish, and the beet leafhopper. In addition, extracts were also included from citrus bacteria ' $C a$. L. asiaticus' and $X$. citri subsp. citri and two other plant-associated bacteria: Xylella fastidiosa isolated from almond and ' $C a$. L. solanacearum' from potato. Amplicons were produced from all $S$. citri sources, whereas no amplicons from non-S. citri samples were obtained (Table 1).

Compared with primer sets based on housekeeping genes, prophage sequence primer set Php-orf1 increased Cq sensitivity of $S$. citri detection by an average of $4.91 \pm 0.49$ standard deviation (SD) and $3.65 \pm 0.62(\mathrm{SD})$ over spiralin and P58 gene primers, respectively. $S$. citri detection by Php-orf3 was slightly less sensi-

Table 4. Mean cycle threshold (Cq) values comparison of real-time polymerase chain reaction based on four primer sets from stored DNA from 73 Spiroplasma citri-positive citrus trees located in two commercial orchards in Huron (southwestern Fresno County) and Ducor (southeastern Tulare County), CA

\begin{tabular}{lcccc}
\hline & \multicolumn{3}{c}{$\begin{array}{c}\text { Average Cq values per primer set per year } \\
\text { for } \text { S. citri detection }\end{array}$} \\
\cline { 2 - 5 } Collection date & Spiralin & P58 & Php-orf1 & Php-orf3 \\
\hline 2007 & 26.08 & 24.75 & 21.64 & 22.98 \\
2008 & 28.23 & 26.59 & 23.17 & 24.38 \\
2009 & 28.61 & 27.39 & 24.97 & 26.68 \\
2011 & 27.85 & 26.03 & 22.99 & 24.58 \\
Average & 27.69 & 26.19 & 23.19 & 24.66 \\
\hline
\end{tabular}

a There were 252 DNA samples extracted using cetyltrimethylammonium bromide method (8) and stored from $73 \mathrm{~S}$. citri-positive trees collected annually over the 4-year sampling period.

Table 3. Primers used in real-time polymerase chain reaction for the detection of Spiroplasma citri

\begin{tabular}{|c|c|c|c|c|c|}
\hline Primer name & Sequence $\left(5^{\prime}-3^{\prime}\right)$ & Target gene & Size & Copy number & Reference \\
\hline \multirow{2}{*}{ Spiralin-F/R } & AAGCAGTGCAAGGAGTTGTAAAAA/ & & & & \\
\hline & TGATGTACCTTTGTTGTCTTGATAAACA & Spiralin & 79 & 1 & 30 \\
\hline \multirow[t]{2}{*}{ P58-F/R } & GTCCCTAATGCACCGTGAAAA/ & & & & \\
\hline & GCACAGCATTTGCCAACTACA & Putative adhesin gene & 119 & 1 & 29 \\
\hline \multirow[t]{2}{*}{ Php-orf1-F/R } & TGGCAGTTTTGTTTAGTCATCC/ & & & & \\
\hline & GGGTCTAAACGCCGTTAAAGT & SpV1-ORF1 & 190 & 13 & This study \\
\hline \multirow[t]{2}{*}{ Php-orf3-F/R } & CTGGTTCACCACAACAAAA/ & & & & \\
\hline & AAACACGGTCGGAGTTTATCA & SpV1-ORF3 & 149 & 11 & This study \\
\hline
\end{tabular}


tive than Php-orf1, with an average Cq of $3.02 \pm 0.62$ (SD) and $1.76 \pm 0.51(\mathrm{SD})$ over spiralin and P58, respectively. Significant differences were obtained using single-factor ANOVA of Cq values comparing spiralin and Php-orf3 $\left(P=6.35 \times 10^{-7}\right)$; and spiralin and Php-orf1 $\left(P=6.59 \times 10^{-11}\right)$. The $\mathrm{Cq}$ value differences between P58 and Php-orf3 or Php-orf1 were also significant $(P=0.001$ and $P=5.47 \times 10^{-8}$, respectively).

Detection limits and PCR amplification efficiency. Ten-fold serial dilutions of genomic DNA of $S$. citri strain LB10 showed high efficiencies of the prophage primer sets (Fig. 1). Standard curve equations of spiralin, P58, Php-orf1, and Php-orf3 primer sets were $Y_{\text {spiralin }}=-3.587 X+34.617, Y_{\mathrm{P} 58}=-3.544 X+29.816$, $Y_{\text {Php-orf1 }}=-3.422 X+27.900$, and $Y_{\text {Php-orf3 }}=-3.543 X+28.075$, respectively. The correlation coefficient of the four standard curves ranged from 0.997 to 1.00 , thus indicating excellent association between template amount and $\mathrm{Cq}$ value. The PCR amplification efficiencies were 90.0, 91.5, 96.0, and 91.5\%, respectively, for each of the primer sets. S. citri detection of DNA from bacterial cells was linear throughout the range of cells tested for all primer sets, indicating that conservative $\mathrm{Cq}$ cutoff values for diagnosis of a $S$. citri-positive sample were 35 and 31 for spiralin and prophage primer sets, respectively. The bacterial detection limits for spiralin and P58 primers were $6.4 \mathrm{fg}$, whereas that for the two prophage primers were $0.64 \mathrm{fg}$. No amplification was obtained when DNA concentration of the LB10 strain was below $0.64 \mathrm{fg}$ per reaction or in the water only control.

Evaluation with CSD-affected field samples. In all, $252 \mathrm{~S}$. cit$r i$-positive sample extracts had been stored at $-80^{\circ} \mathrm{C}$ from $73 \mathrm{~S}$. citri-infected trees from the Huron and Ducor plots (Table 4). These samples had been collected annually over a 4-year period (2007 to 2011) and used in this study. S. citri was detected in 240 (95.24\%), 243 (96.43\%), 250 (99.21\%), and 249 (98.81\%) extracts by spiralin, P58, Php-orf1, and Php-orf3 primer sets, respectively. The mean $\mathrm{Cq}$ values of field samples also indicated that the prophage primers had greater detection sensitivity than spiralin and P58 (Table 4). Because this analysis did not include samples from S. citri-negative trees, confirmation of false-negative samples from housekeeping gene primer sets was confirmed by positive tests with the two prophage primer sets. S. citri detection from field samples was also evaluated in another set of multiple-year samples from 568 field trees (Table 5). This analysis differed from the $\mathrm{Hu}-$ ron or Ducor set because all trees sampled including those not infected were tested by primer sets spiralin and Php-orf1. In 2010, the DNA was extracted by CTAB and the spiralin primer set detected 102 infected trees; whereas Php-orf1 detected 108 trees. In 2013, the same trees were sampled but DNA was obtained by highthroughput extraction. The spiralin primers detected 106 infected trees while Php-orf1 detected 112. Thus, in 2010 and 2013, the prophage primer set found six additional infected trees (confirmed by a separate test with Php-orf3) compared with the spiralin primer set. Based on redundant assays with primer sets from different gene regions, no false-positive results were detected with any of the primer sets. Therefore, the false readings using housekeeping genes were approximately $1 \%(6 / 568)$ and approximately $5 \%$ (6/112) if only positive samples were considered versus the prophage primer sets. The average $\mathrm{Cq}$ value for infected trees sampled in 2010 and DNA extracted by CTAB was 31.3 and 27.8 for spiralin and Php-orf1, respectively; and, in 2013 samples processed by high-throughput extraction, was 32.8 versus 26.8 for spiralin and Php-orf1, respectively.

\section{Discussion}

Current qPCR assays for S. citri target low-copy housekeeping genes of $S$. citri, which have the characteristics of high fidelity and specificity. However, due to the low ratio of $S$. citri DNA relative to background DNA within samples, detection of low titer levels of the pathogen can be unreliable. Alternatives such as nested PCR (10) or Bio-PCR (26) are not convenient for large-scale surveys due to increased handling and potential for contamination. Deep sequencing of $S$. citri strains extended the genomic information available for improved PCR detection of the pathogen. Phagerelated sequences from $S$. citri strain GII3-3X were obtained from Illumina sequencing of eight $S$. citri strains (R. K. Yokomi, unpublished data). Because the single-copy nature of 16S rRNA gene in the nine strains examined was expected $(7,28)$, sequence duplication in these genomes was minimal and predicted gene copy numbers were acceptable. The high copy numbers of the two prophage genes in the $S$. citri genomes sequenced showed that prophage genes in S. citri were ubiquitous and abundant. There are other reports of multiple copies of SpV1-type phages or at least contain SpV1-related sequences in chromosomal DNA of $S$. citri $(2,7,27)$. Based on prophage genes with tandem repeats, Morgan et al. (18) developed a qPCR method which could improve detection sensitivity of ' $\mathrm{Ca}$. L. asiaticus'. In the present study, two newly developed primer sets, Php-orf1 and Php-orf3, were selected from two $S$. citri phage or prophage genes, SpV1-ORF1 and SpV1ORF3. These two genes are annotated as a hypothetic protein and a putative transposase, respectively.

The prophage primers readily detected all $S$. citri strains tested and sensitivity of qPCR assays was improved more than 10-fold from that of spiralin or the putative P58 adhesin gene. The in silico match of Php-orf1 sequences with $S$. citri and S. kunkelii, causal agent of corn stunt disease (4), exemplifies the risk of false positives with the exclusive use of nonhousekeeping genes for PCR detection of the pathogen. As was done in this study, primer sets to several conserved housekeeping genes should be included to confirm PCR detection.

Primer sets Php-orf1 and Php-orf3 resulted in significantly lower mean $\mathrm{Cq}$ values regardless of how the target DNA was acquired. Use of the prophage primers in qPCR assays with field samples

Table 5. Cycle threshold $(\mathrm{Cq})$ values to detect Spiroplasma citri-infected citrus trees by real-time polymerase chain reaction comparing primer sets of spiralin versus Php-orf1 with SYBR Green

\begin{tabular}{|c|c|c|c|c|c|}
\hline \multirow[b]{3}{*}{ Plot $^{\mathrm{d}}$} & \multirow[b]{3}{*}{ Number of trees } & \multicolumn{4}{|c|}{ Number of $S$. citri-positive Cq values ${ }^{\mathrm{a}}$} \\
\hline & & \multicolumn{2}{|c|}{2010 CTAB $^{b}$} & \multicolumn{2}{|c|}{2013 HTE $^{c}$} \\
\hline & & Spiralin & Php-orf1 & Spiralin & Php-orf1 \\
\hline 1 & 256 & 37 & 37 & 40 & 39 \\
\hline 2 & 64 & 12 & 15 & 16 & 16 \\
\hline 3 & 64 & 19 & 20 & 19 & 19 \\
\hline 4 & 57 & 5 & 5 & 6 & 10 \\
\hline 5 & 63 & 7 & 9 & 8 & 9 \\
\hline 6 & 64 & 23 & 22 & 17 & 19 \\
\hline Totals & 568 & 102 & 108 & 106 & 112 \\
\hline Infection (\%) & $\ldots$ & 18.0 & 18.7 & 18.7 & 19.7 \\
\hline Average $\mathrm{Cq}$ & $\ldots$ & $31.3 \pm 2.0$ & $27.8 \pm 3.2$ & $32.8 \pm 2.0$ & $26.8 \pm 2.3$ \\
\hline
\end{tabular}

${ }^{a}$ Conservative cut off $\mathrm{Cq}$ values for positive diagnosis of $S$. citri-infection in citrus tissue samples were 35 and 31 for spiralin and prophage primers, respectively.

${ }^{b}$ Target DNA extraction (2010) by cetyltrimethylammonium bromide (CTAB) method (8).

c Target DNA extraction (2013) by high-throughput extraction (HTE) (25).

${ }^{\mathrm{d}}$ Citrus cultivar in plot was Cara Cara on Carrizo rootstock planted in 2007 near Mettler, Kern County, CA. 
showed its value by detecting $S$. citri infection from samples previously evaluated as negative by qPCR with housekeeping genes. Reducing the risk of false negatives is critically important if PCR diagnosis of $S$. citri infection is used in certification programs.

Due to the abundance of repeated sequences, many related to phages or prophages, closure of the $S$. citri chromosome was not successful $(7,24)$. Recently, the complete genomes of $S$. chrysopicola and S. syrphidicola were reported (11). Interestingly, these two species did not contain plectroviral genes. With regard to the virus-free genomes, further analyses suggested that phage invasions were critical for horizontal gene transfers that contributed to the bacterial environmental adaptation (11). Nevertheless, data
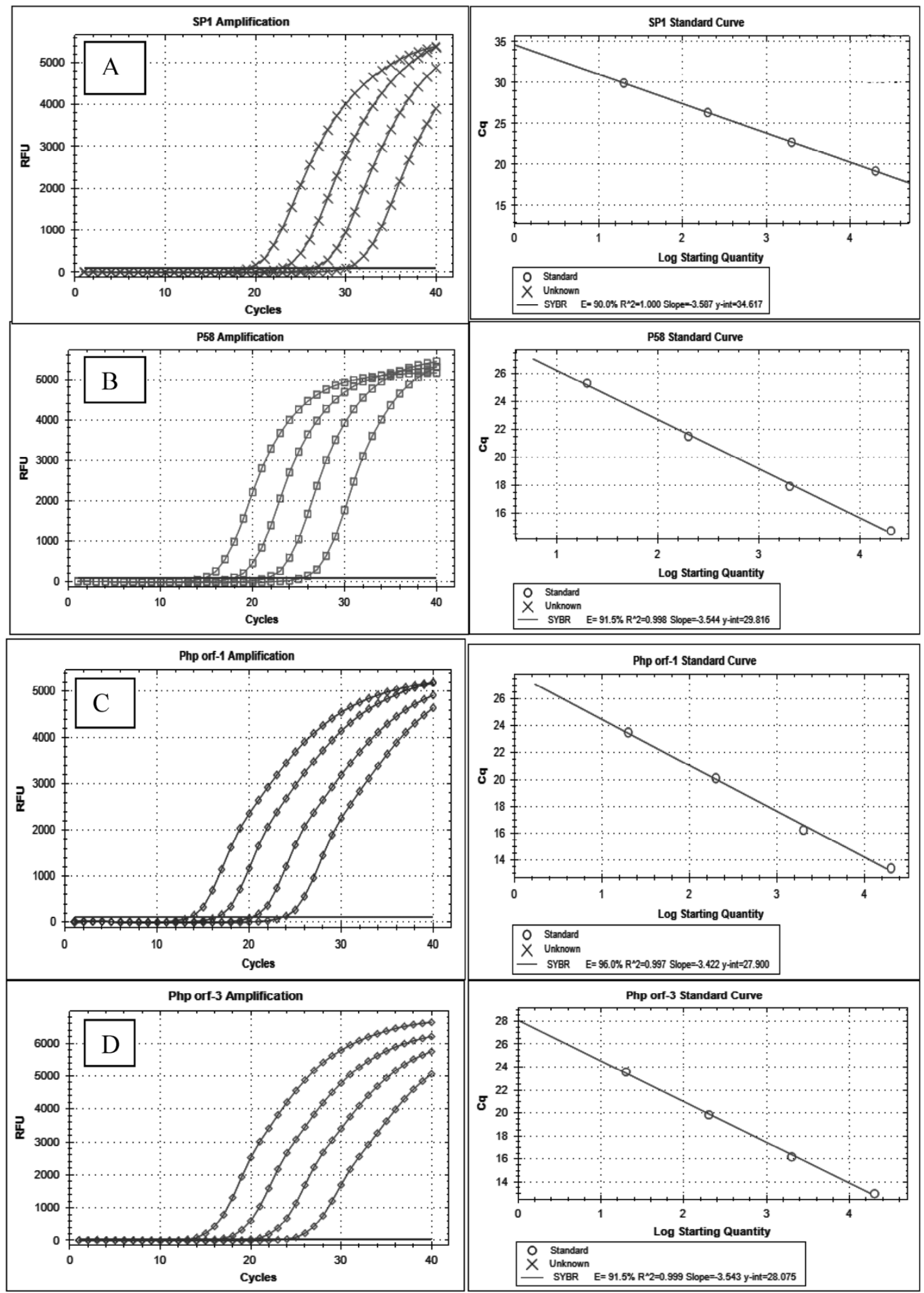

Fig. 1. Standard curve of cycle threshold (Cq) values of 10-fold dilution DNA extracted from Spiroplasma citri (LB10) at 20,000 cells/ $\mu$ in quantitative polymerase chain reaction assays with the different gene primer sets. Each reaction contained $1 \mu$ l of cell suspension and the reporting dye was SYBR Green. A, Spiralin; B, P58; C, Php-orf-1; and D, Php-orf-3. RFU = relative fluorescence units. 
mining from additional sequencing efforts will be helpful to screening additional genomic loci with potential to further improve detection of $S$. citri. It is interesting to note that the primer set Php-orf1 could target the gene in $S$. kunkelii via in silico analysis, suggesting that it also has the potential to improve detection of $S$. kunkelii, in which the plectroviral genes were found to be abundant $(1,31)$.

In conclusion, qPCR targeting high-copy-number genes such as SpV1-ORF1 significantly improved $S$. citri detection in culture and field samples. These results were validated by side-by-side qPCR using housekeeping and prophage gene primers. The increased sensitivity has additional value for early detection of the disease agent. The addition of automated high-throughput DNA extraction increased laboratory processing efficiency, reduced pipetting errors, and improved standardization needed for large-scale field surveys for epidemiology studies.

\section{Acknowledgments}

This work was supported, in part, by the California Citrus Research Board (5300-151), Specialty Crops Block Grant SCB 10005 from the California Department of Food and Agriculture, and a China Scholarship Council grant to X. Wang. We thank J. Fletcher, Oklahoma State University, Stillwater, for some of the original bacterial cultures sequenced; and G. Phillip, R. Huerta, R. DeBorde, S. Lunden, and C. Crockett from the USDA, ARS, PWA, CDPG, Parlier, CA for their technical assistance.

\section{Literature Cited}

1. Bai, X., and Hogenhout, S. A. 2002. A genome sequence survey of the mollicute corn stunt spiroplasma Spiroplasma kunkelii. FEMS Microbiol. Lett. 210:7-17.

2. Bébéar, C. M., Aullo, P., Bové, J. M., and Renaudin, J. 1996. Spiroplasma citri virus SpV1: Characterization of viral sequences present in the spiroplasmal host chromosome. Curr. Microbiol. 32:134-140.

3. Bové, J. M., and Garnier, M. 2000. Stubborn. Pages 48-50 in: Compendium of Citrus Diseases. L. W. Timmer, S. M. Garnsey, and J. H. Graham, eds. American Phytopathological Society, St. Paul, MN.

4. Bradfute, O. E., Tsai, J. H., and Gordon, D. T. 1981. Corn stunt spiroplasma and viruses associated with a maize disease epidemic in southern Florida. Plant Dis. 65:837-841.

5. Calavan, E. C., and Oldfield, G. N. 1979. Symptomatology of spiroplasmal plant disease. Pages 37-64 in: The Mycoplasmas. R. F. Whitcomb and J. G. Tully, eds. Academic Press, Inc., New York.

6. Camacho, C., Coulouris, G., Avaqyan, V., Ma, N., Papadopoulos, J., Bealer, K., and Madden, T. L. 2009. BLAST+: Architecture and applications. BMC Bioinf. 10:421.

7. Carle, P., Saillard, C., Carrère, N., Carrère, S., Duret, S., Eveillard, S., Gaurivaud, P., Gourgues, G., Gouzy, J., Salar, P., Verdin, E., Breton, M., Blanchard, A., Laigret, F., Bové, J. M., Renaudin, J., and Foissac, X., 2010. Partial chromosome sequence of Spiroplasma citri reveals extensive viral invasion and important gene decay. Appl. Environ. Microbiol. 76:34203426.

8. Doyle, J. J. 1991. DNA protocols for plants. Pages 283-293 in: Molecular Techniques in Taxonomy. G. Hewitt, A. W. B. Johnson, and J. P. W. Young, eds. NATO ASI Ser. H, Cell Biol. 57. Springer-Verlag, Berlin.

9. Gumpf, D. J., and Calavan, E. C. 1981. Stubborn disease of citrus. Pages 97-134 in: Mycoplasma Diseases of Trees and Shrubs. K. Maramorosch and S. P. Raychaudhuri, eds. Academic Press, New York.

10. Haff, L. A. 1994. Improved quantitative PCR using nested primers. Genome Res. 3:332-337.

11. Ku, C., Lo, W. S., Chen, L. L., and Kuo, C H. 2013. Complete genomes of two dipteran-associated spiroplasmas provided insights into the origin, dynamics, and impacts of viral invasion in Spiroplasma. Genome Biol. Evol. 5:1151-1164.
12. Lee, I. M., Bottner, K. D., Munyaneza, J. E., Davis, R. E., Crosslin, J. M. du Toit, L. J., and Crosby, T. 2006. Carrot purple leaf: A new spiroplasmal disease associated with carrots in Washington State. Plant Dis. 90:989-993.

13. Li, R., Li, Y., Kristiansen, K., and Wang, J. 2008. SOAP: Short Oligonucleotide Alignment Program. Bioinformatics 24:713-714.

14. Li, W., Hartung, J. S., and Levy, L. 2006. Quantitative real-time PCR for detection and identification of 'Candidatus Liberibacter' species associated with citrus huanglongbing. J. Microbiol. Methods 66:104-115.

15. Liu, H-.Y., Gumpf, D. J., Oldfield, G. N., and Calavan, E. C. 1983. The relationship of Spiroplasma citri and Circulifer tenellus. Phytopathology 73:585-590.

16. Melcher, U., Sha, Y., Ye, F. C., and Fletcher, J. 1999. Mechanisms of Spiroplasma genome variation associated with SpV1-like viral DNA inferred from sequence comparisons. Microb. Comp. Genomics 4:29-46.

17. Mello, A. F. S., Yokomi, R. K., Melcher, U., Chen, J. C., Wayadande, A. C. and Fletcher, J. 2008. Genetic diversity of Spiroplasma citri strains from different regions, hosts, and isolation dates. Phytopathology 98:960-968.

18. Morgan, J. K., Zhou, L. J., Li, W., Shatters, R. G., Keremane, M., and Duan, Y. P. 2012. Improved real-time PCR detection of 'Candidatus Liberibacter asiaticus' from citrus and psyllid hosts by targeting the intragenic tandemrepeats of its prophage genes. Mol. Cell. Probes 26:90-98.

19. Nejat, N., Vadamalai, G., and Dickinson, M. 2011. Spiroplasma citri: A wide host range phytopathogen. Plant Pathol. J. 10:46-56.

20. Nejat, N., Vadamalai, G., Sijam, K., and Dickinson, M. 2011. First report of Spiroplasma citri associated with periwinkle lethal yellows in Southeast Asia. Plant Dis. 95:1312.

21. Oldfield, G. N., Kaloostian, G. L., Pierce, H. D., Calavan, E. C., Granett, A. L., Blue, R. L., Rana, G. L., and Gumpf, D. J. 1977. Transmission of Spiroplasma citri from citrus to citrus by Scaphytopius nitridus. Phytopathology 67:763-765.

22. Renaudin, J., Aullo, P., Vignault, J. C., and Bové, J. M. 1990. Complete nucleotide sequence of the genome of Spiroplasma citri virus SpV1-R8A2 B. Nucleic Acids Res. 18:5.

23. Rozen, S., and Skaletsky, H. J. 2000. Primer 3 on the WWW for general users and for biological programmers. Methods Mol. Biol. 132:365-386.

24. Saillard, C., Carle, P., Duret-Nurbel, S., Henri, R., Killiny, N., Carrère, S., Gouzy, J., Bové, J. M., Renaudin, J., and Foissac, X. 2008. The abundant extrachromosomal content of Spiroplasma citri strain GII3-3X. BMC Genomics 9:195-207.

25. Saponari, M., Loconsole, G., Liao, H.-H., Jiang, B., Savino, V., and Yokomi, R. K. 2013. Validation of high-throughput real time polymerase chain reaction assays for simultaneous detection of invasive citrus pathogens. J. Virol. Methods 193:478-486:

26. Schaad, N. W., Cheong, S. S., Tamaki, S., Hatziloukas, E., and Panopoulos, N. J. 1995. A combined biological and enzymatic amplification (BIO-PCR) technique to detect Pseudomonas syringae pv. phaseolicola in bean seed extracts. Phytopathology 85:243-248.

27. Ye, F. C., Laigret, F., Carle, P., and Bové, J. M. 1995. Chromosomal heterogeneity among various strains of Spiroplasma citri. Int. J. Syst. Bacteriol. 45:729-734.

28. Ye, F. C., Laigret, F., Whitley, J. C., Citti, C., Finch, L. R., Carle, P., Renaudin, J., and Bové, J. M. 1992. A physical and genetic map of the Spiroplasma citri genome. Nucleic Acids Res. 20:1559-1565.

29. Yokomi, R. K., Mello, A. F. S., Saponari, M., and Fletcher, J., 2008. Polymerase chain reaction-based detection of Spiroplasma citri associated with citrus stubborn disease. Plant Dis. 92:253-260.

30. Yokomi, R. K., and Sisterson, M. 2011. Validation and comparison of a hierarchal sampling plan for estimating incidence of citrus stubborn disease. In: Proc. 18th Conf. Int. Organ. Citrus Virol. IOCV, Riverside, CA. http://iocv.org/proceedings/eighteen/Yokomi_and_Sisterson.pdf

31. Zhao, Y., Hammond, R. W., Jomantiene, R., Dally, E. L., Lee, I. M., Jia, H., Wu, H., Lin, S., Zhang, P., Kenton, S., Najar, F. Z., Hua, A., Roe, B. A., Fletcher, J., and Davis, R. E. 2003. Gene content and organization of an 85kb DNA segment from the genome of the phytopathogenic mollicute Spiroplasma kunkelii. Mol. Genet. Genomics 269:592-602. 